\title{
CHALLENGES IN FORMULATING HERBAL COSMETICS
}

\author{
SIRI SINDHURA D. K. ${ }^{1}$, VIKAS JAIN ${ }^{*}$ \\ 1Department of Pharmaceutics, JSS College of Pharmacy, JSS Academy of Higher Education and Research, Mysore 570015, Karnataka, \\ India \\ Email: vikasjain@jssuni.edu.in \\ Received: 18 May 2018, Revised and Accepted: 12 Sep 2018
}

\begin{abstract}
The herbal cosmetics are prepared by phytochemicals that occur in a variety of botanical sources, that influences the physiology of skin and provide nutrients that are necessary for the healthy skin or hair. These products are utilized for daily purposes, which include herbal shampoo, herbal conditioner, herbal face wash, herbal soap, etc. These products are classified as a different category by regulatory agencies. However, guidelines of these certifying agencies have no harmonization, and many cosmetic industries prepare and package these formulations in an irrationalway. Many cosmetic products have natural products in their formulation that perform a specific biological function, but these products should be evaluated on their toxicological and efficacy aspects. The contribution of developing countries is very poor in global herbal business because of lack of standardization measures and quality control. The lack of safety and efficacy data on herbal cosmetics renders it difficult to meet the criteria needed for supporting its use worldwide. This review article discusses challenges related to regulatory status, quality control, standardization, certification, drug processing and the opportunities for herbal cosmetics in local as well as the global scenario. The search criteria used in the present review were the keywords mentioned in the manuscript and articles from major scientific resources were cited. The articles from 1952 to 2018 were specifically referred, but few references from 19 century were also cited to support the prevalence of scientific principles in the development of herbal cosmetics in the ancient era.
\end{abstract}

Keywords: Challenges, Herbal cosmetics, Regulatory, Quality

(C) 2018 The Authors. Published by Innovare Academic Sciences Pvt Ltd. This is an open access article under the CC BY license (http://creativecommons.org/licenses/by/4.0/) DOI: http://dx.doi.org/10.22159/ijap.2018v10i6.27377

\section{INTRODUCTION}

The cosmetics, according to the Drugs and Cosmetics Act is defined as articles intended to be rubbed, poured, sprinkled or sprayed on, introduced into or otherwise applied to the human body or any part thereof for cleansing, beautifying, promoting attractiveness or altering the appearance. The cosmetic does not come under the preview of the drug license [1]. The natural herbs and their products when utilized for their sweet-smelling an incentive in corrective planning are named as natural beautifying agents [2]. There is the regular conviction that compound based beautifiers are destructive to the skin and expanded mindfulness among consumers for natural extracts set off the interest for common items and normal concentrates in beautifying agents arrangements [3, 4]. According to the United States, Food and Drug Administration (US FDA), the Food, Drugs, and Cosmetics Act; A product can be a drug, a cosmetic, or a combination of both, but the term "Cosmeceuticals" has no meaning under the law" [5]. So, the term Cosmeceuticals is not recognized by the Federal Food, Drug, and Cosmetic Act. In spite of the fact that beauty care products and Cosmeceuticals are tried for wellbeing, testing to decide if valuable fixings satisfy a manufacturer's cases isn't required [6]. When all is said in done, vitamins, herbs, different oils, and organic concentrates might be utilized as a part of Cosmeceuticals, however, the manufacturer may not assert that these items penetrate the skin's surface layers or that they have therapeutic effects $[7,8]$. A major factor impeding the development of the medicinal plant-based industries in developing countries has been the lack of information on the social and economic benefits that could be derived from the industrial utilization of medicinal plants. Except for the use of these plants for local health care needs, not much information has been available on their market potential and trading possibilities. These challenges in formulating a herbal cosmetic or a product, in general, are being discussed in this article $[9,10]$.

\section{History}

The word cosmetic was derived from the Greek word "kosmtikos" meaning having the power, arrange, skill in decorating [11]. The word cosmetics defined as "Substances of diverse origin, scientifically compounded and used to i) cleanse, ii) allay skin troubles, iii) cover up imperfections and iv) beautify". The origin of cosmetics forms a continuous narrative throughout the history of man as they developed. This origin of cosmetics was associated with chasing, battling, religion and superstition and later connected with medicine [12]. The man in ancient circumstances utilized hues for improvement to draw in the creatures that he wished to chase, and the man survived an assault from the adversary by shading his skin and embellished his body for insurance to incite fear in a foe (regardless of whether man or creature) [13]. Ashtanga Hridaya (a 1500-year-old book of Ayurveda) offers six unique plans to be utilized for the six periods of the year.

Special Tailams (Oils) and Ghritas (Clarified spread or ghee) were utilized for facial beautification. Unnecessary hair was thought to be a disgrace, and a substantial number of depilatory specialists were prescribed to dispose of it. Special ingredients were utilized for hair washes [14]. Numerous cures have been demonstrated for hair development, the counteractive action of falling hair and untimely turning grey [15]. Hair colours, fragrant hair washes, and fumigants were likewise being used. Fragrant shower powders and body antiperspirants were additionally used [16]

Oral cleanliness as care of teeth, mouth antiperspirants and shading of lips were everyday errands to be religiously sought after [17]. It gives the idea that the full scope of present-day corrective use was brought about by the ancient Indians and was rehearsed with the assistance of natural products that were available [18].

The information at last separated from drug lastly to pharmacy. The man from ancient time had the magic tip towards impressing others with their look. The time during which there was no fairness creams or any cosmetics surgeries to modify the appearance, the skin and hair excellence of people relies upon the wellbeing, propensities, routine employment, climatic conditions and support. The skin because of exorbitant introduction to warmth will get dried out amid summer and causes wrinkle, spots, flaws, pigmentation and sunburns. The outrageous winter make harms the skin as breaks, cuts, maceration, and contaminations [19-22].

The main factor they needed to depend on was the information of nature arranged in the Ayurveda. The art of Ayurveda had used numerous herbs and verdures to make beauty care products for beautification and security from outside influences [23]. The normal 
substance in the botanicals does not bring about any reactions on the human body; rather enhance the body with supplements and other helpful minerals [24].

The Drug and Cosmetics Act indicate that herbs and basic oils utilized as a part of beautifying agents must not claim to enter past the surface layers of the skin nor ought to have any helpful impact [25]. The lawful prerequisite and the administrative techniques for natural beauty care products are the same as that for other synthetic chemicals utilized as a part of cosmetic formulations [26].

\section{Challenges}

\section{Ethnic Factors}

It includes the factors that affect the nature of the drug at the time of cultivation of herbs.

- Light
- Temperature
- Atmospheric humidity
- Altitude
- Rainfall
- Soil

Any variations in the above factors affect the nature of the drug resulting in the alteration of the number of active constituents present in the herbs which becomes challenging while formulating herbal cosmetics.

\section{Regulatory status of herbal drugs}

WHO guidelines state that both manufacturers and regulatory bodies should share equal responsibility to assure the quality of herbal products [32]. It is the duty of regulatory authorities to establish some ground guidelines on various aspects of quality assurance, data evaluation, dossiers and evaluation of postmarketing compliance of products with the specifications set out by the manufacturers as well to comply with GMP guidelines [33-35].

It is of chief importance that the manufacturers firmly stick to good agricultural and further good collection practices (GACP), GMP and good laboratory practice (GLP) standards, to establish proper specifications for their finished products, raw materials, and intermediates and to gather whole documentation on the herbal development and testing. The producers must keep in pace with the current information with respect to manufacturing and marketing of products [36].

In WHO summit in 2000, several recommendations for quality control of farming of raw materials of herbal formulations were put forth. During this summit, it was recommended that a subcommittee should be formed on GACP to make sure superior quality of herbal products are made available to the market by providing proper training to small manufacturers and farmers [37].

For the implementation of GACP, incentives can be given to manufacturers of raw materials. These incentives take in consideration giving technical and logistic support in the selection of suitable areas for the agricultural purpose, giving appropriate seeds and seedlings, selecting pesticides and fertilizers, providing advice on equipment for harvesting, and further processing [38].

The national drug regulatory authority should safeguard the issue of license for manufacturers, wholesalers, importers, and assemblers of herbal medicinal [39]. One or more licences are needed to be applied by the dealers of imported herbal products depending on the type of business involved [40].

One of the departments that ensure the quality of the products by following well-organized and standard specifications is Quality Control. These standard specifications can be found in official pharmacopoeia, monographs, etc. Many analytical techniques are used to check the quality of herbal products. Detailed information of the herbal products with a list of all ingredients, formula of the product for imported herbal-based products for the registration of herbal products [41-43]. The details of manufacturer(s) and their licence or certificate from the drug regulatory authority, brand name of product, dosage form and dosage, indications, administration mode, duration of use, adverse effects, any contraindications, warnings, important precautions, lot/batch number, and any possible drug interactions, manufacturing and expiry date of the product and conditions for storage. To assess and gather data about the safety and efficacy of herbal products simultaneously watching for adverse drug reactions, pharmacovigilance centres are required [45-47].

\section{Product certification}

The main objective of the certification of a product is to check the ingredients including raw materials, processes, production and manufacturing, raw materials storage, packaging and labelling, energy resources usage and waste disposal management, also the certification of manufacturers to certify the quality of the end product. The certification agencies execute standards that should be satisfied by the manufacturer, to be able to ensure the quality of the final product [48].

\section{The major certification agencies for natural and organic products are}

1. Bundesverb and Deutscher Industrie und Handel sunternehmen (BDIH) in Germany: BDIH is the non-governmental association of Trading Firms and industries for pharmaceuticals, food supplements, health care products, and personal care products. This is located in Mannheim, Germany and has organized over 440 distributors and producers of:

\section{- Cosmetics and Natural Cosmetics \\ - Nutritional and Food supplements \\ - OTC Medications \\ - Medical Devices}

2. Soil association organic standard in the United Kingdom: The Soil Association is based on a charitable trust in the UK, which was found in 1946. It has about 27,000 members. Its activities contain campaign work on concerns including backing for local purchasing. It opposes the intensive farming. And gives training on nutrition and the certification of organic food.

3. Cosmetics organic standard (Cosmos) in European Union (EU): The COSMOS standard is owned and organized by an international nonprofit and non-governmental organization which is registered in Belgium. Its main objective is to guard the welfare of the environment and of people, in cosmetics. The COSMOS standards simulate the development of cosmetics that are ever more organic and assure the consumers that they have clear and transparent information.

4. ECOCERT in france: Ecocert is an association of organic certification, found in France in 1991. It is originally based in Europe but examines in over 80 countries, which makes it one of the major organic certification organizations in the world.

5. National association for sustainable agriculture, australia (NASAA) in australia: It was formed in 1986, which is a non-profit membership based organization, whose contract is "to maintain the education of industry and customers on organic, sustainable and biodynamic agricultural practices".

6. Istituto per la certificazione etica e ambientale (ICEA) in Italy: It is an independent and qualified Certification Institute which is a non-profit consortium consisting of experts in panels and certifications concerned with ethical standards and ecological sustainability.

7. Instituto Biodinâmico de Certificações (IBD) in Brazil: IBD is the chief certifier in Latin America and the only Brazilian certifier of natural products with USDA/NOP (North American market), IFOAM (international market), Demeter (international market), European market-regulation and permitted for usage of the SISORG, a Brazilian market seal, which makes its certificate accepted globally. 
8. Oregon Tilth in the United States of America: OTCO is the organization for certification program which was established in 1982 and involves in certification actions for agricultural and product manufacturers and other handlers of natural products.

9. Quality assurance international (QAI) in the united states of America: This is a U.S. based international organic certification organization that is approved by the United States Department Agriculture (USDA) as "a USDA-accredited certifying agent that functions globally to certify organic procedures to National Organic Program principles." It is a profit corporation which is established in 1989 and headquartered in San Diego, California [44-51].

\section{Quality control of herbal drugs and cosmetics}

To choose an extracting solvent, the nature of the compounds involved should be considered and might be concluded from the traditional uses. For example, when a tea is made from a herbal drug, the extractable matter from hot water, which is expressed as milligrams per gram of airdried material [57]. When the active elements are known, a huge collection of modern chemical analytical methods such as HPLC, GC, UV or visible spectroscopy (UV/VIS), TLC, mass spectrometry (MS), or a mix of GC and MS (GC/MS), can be performed [52].

Precision, validity, accuracy, robustness of the equipment plays a major role in choosing an analytical method. Availability of sophisticated techniques such as HPLC-high-performance liquid chromatography, MSmass spectrometry, and GC-Gas chromatography, making it possible to find as well as measure the test substance $[53,54]$.

Several factors influence the quality of herbal drugs. They are;

1. Herbal drugs are a combination of several constituents.

2. In most cases, the active principle(s) is/are, unidentified.

3. Analytical methods that are suitable or standard references may not be available commercially [55].

4. Plant actives are chemically and naturally inconstant.

5. The raw material source and quality are unstable [56].

6. The methods of collecting, drying, storage, transportation, and processing have a variable effect on the final product.

7. Firm guidelines have to be followed for the production of a herbal product with superior quality. Proper plant identification, phytochemical screening, and standardization can be the criteria to look for [57,58].

It plays a key role in assuring the quality and steadiness of herbal products, the quality of a plant product is determined by the dominant conditions during development and recognized Good Agricultural Practices (GAP) can regulate this [59].

These include seed assortment, growth environment, and use of fertilizers, reaping, drying and storing. GAP procedures are and will be, a vital part of quality regulation [60].

Factors such as the usage of new plants, age and part of plant gathered, period, time and technique for accumulation, the temperature of the process, light introduction, water accessibility, supplements, drying, pressing, transportation and capacity of the crude material, can incredibly affect the quality [61].

Apart from these standards, influences such as the extraction method, microbial contamination, presence of heavy metals, and pesticides can alter the quality, safety, and efficacy of herbal drugs [62]. Using cultivated plants under controlled conditions instead of those collected from the wild can minimize most of these factors sometimes the active principles are destroyed by enzymes processes that continue for prolonged periods from collection to marketing, resulting in a variation of composition. Thus, proper standardization and quality control of both the raw material and the herbal preparations should be conducted $[63,64]$.

\section{Evidence of clinical efficacy}

Scientific evidence from randomized clinical trials is only strong for many uses of acupuncture, some herbal medicines and for some of the manual therapies. Only a small fraction of the thousands of medicinal plants used worldwide has been tested rigorously in randomized, controlled trials [65]. Even if the animal studies or anecdotal clinical experiences are promising and use of a herb is widespread, such observations cannot predict the results of welldesigned randomized, controlled trials. A recent review concluded that evidence-based studies on the efficacy and safety of traditional Indian medicines are limited. The data available is mostly experimental or in animals $[66,67]$.

\section{Standardization}

It involves adjusting the herbal drug preparation to a defined content of a constituent or a group of substances with known therapeutic activity by adding excipients or by mixing herbal drugs or herbal drug preparations [68]. Botanical extracts made directly from crude plant material show substantial variation in composition, quality, and therapeutic effects. Standardized extracts are highquality extracts containing consistent levels of specified compounds, and they are subjected to rigorous quality controls during all phases of the growing, harvesting, and manufacturing processes. No regulatory definition exists for the standardization of dietary supplements [69].

As a result, the term "standardization" may mean many different things. Some manufacturers use the term standardization incorrectly to refer to uniform manufacturing practices; following a recipe is not sufficient for a product to be called standardized. Therefore, the presence of the word "standardized" on a supplement label does not necessarily indicate product quality [70].

When the active principles are unknown, the marker substance(s) should be established for analytical purposes and standardization $[71,72]$. Marker substances are chemically defined constituents of a herbal drug that is important for the quality of the finished product. Ideally, the chemical markers chosen would also be the compounds that are responsible for the botanical effects in the body [73, 74].

There are two types of standardization. In the first category, "true" standardization, a definite Phytochemical or group of constituents is known to have activity [75]. Ginkgo with its $26 \%$ ginkgo flavones and $6 \%$ terpenes is a classic example. These items don't represent the entire herb and are presently considered as phytopharmaceuticals. By and large, they are boundlessly more viable than the entire herb [76]. In any case, the procedure may bring about the loss of adequacy and the potential for unfavorable impacts and herb-drug interactions may increment [77]. The other sort of standardization depends on makers ensuring the nearness of a specific level of marker aggravates; these are not pointers of therapeutic effect or nature of the herb. On account of natural medication arrangements, the generation and primary step of the medicinal plant or natural medication impacts the nature of the APIs, because of the multifaceted nature of normally developing therapeutic plants and the constrained accessibility of basic explanatory methods. To recognize and portray the dynamic constituents exclusively by synthetic or organic means, there is a requirement for a satisfactory quality affirmation framework. This confirmation is additionally required amid development, gathering, essential preparing, capacity, packaging, and distribution [78-80].

Deterioration and contamination through adulteration, especially microbial contamination, can occur at any one of these stages. It is extremely important to establish good agricultural, harvesting, and manufacturing practices for herbal starting materials in order to minimize this undesirable factor [81].

In such manner manufacturers, processors, and traders of therapeutic plants or natural medications have a commitment and a part to play. The makers and suppliers of natural products should cling to quality control standards and GMP' well-being via doing re-market surveys of all medications previously they are approved available to be purchased. The items accessible in the market are investigated routinely to guarantee that they are free of harmful ingredients and that the products contain ingredients mentioned as such in labels $[82,83]$.

This procedure requires high information in the Phytochemical investigation and process innovation to guarantee the quality 
affirmation required. The expansion of significant worth in natural products as numerous procedures inside the phytochemical business is comparative or indistinguishable to unit tasks inside the synthetic building. It demonstrates the likenesses in unit operations and Phytochemical preparing techniques between conventional synthetic designing and Phytochemical handling [84-85]. Many areas of chemical engineering would be applicable to the phytochemical industry. In terms of basic knowledge Chemical engineers need to emphasize on acquiring more data on: -

\section{- Organic Chemistry-Natural products chemistry in particular}

\section{- Analytical Methods-such as HPLC, LC-MS, NMR}

Among key issues that must be tended to incorporate creating process plan information for homegrown extraction. Currently, much natural extraction configuration is done in light of learning from food technologists. Regularly these outline techniques don't consider compound thermodynamic information or plan strategies. Process models are fabricated are not effectively reproduced or used the same number of depending on surface reaction philosophies which are just relevant to the gear examined. More first principle modeling methods need to be developed to model, optimizes, and scale up herbal extraction processes [86-87].

\section{Processing and GMP}

There are major processes in natural therapeutic products fabricating beginning from natural yield planting to manufacturing and advertising. Chemical designers are included once the herb is gathered where speedy pre-preparing and stockpiling is required. Pre-handling includes diminishing the span of the herb through chopping and granulating to get ready for preparing while great stockpiling technique guarantees that the dynamic Phytochemicals are kept up before handling [88-89].

Processing is a basic part of herbal product generation, particularly because of the low yield of concentrates. Handling techniques are generally in light of conventional strategies, for example, highweight water extraction for herbs which are customarily bubbled as decoctions. New inventive strategies, for example, Supercritical Fluid Extraction (SFE) where supercritical liquids, for example, carbon dioxide under high pressure are used to deliver natural concentrates should be created to deliver homegrown results of higher yield, bring down working expenses, and speedier generation times. Packaging and sale take place after processing [90-91].

Good Manufacturing Practice (GMP) is a code of training utilized by the medical and health-related industries incorporating the pharmaceutical business with an end goal to keep up the most elevated standards of value in the improvement, manufacture, and control of therapeutic products [92].

\section{Toxicity of traditional herbal drugs}

Herbs generally can cause either digestive upset or allergic reactions. Digestive upset can result from taking some herbs like standardized ginkgo extract, especially on an empty stomach. In their whole form, herbs have lots of crude fibre and can be tough to digest for some people. Herb extracts are often easier to digest and usually cause a less digestive upset, though even extracts can cause a feeling of nausea or fullness to occur in some cases. Adverse drug reactions, allergic reactions, drug interactions, herb-drug interactions, contamination of the drug, false authentication of the drug are some of the other challenges that come into consideration when spoke about herbal cosmetics [93, 94].

\section{DISCUSSION}

Herbal Cosmetics are referred to as Products, are formulated, using various permissible cosmetic ingredients. Herbal cosmetics are also known as "natural cosmetics. The various ingredients which are used for herbal cosmetics are Aloe Vera gel, cucumber extract, honey, lemon oil, etc. In the formulation of herbal cosmetics mainly herbal skin care products, hair care, lip care, eye care, herbal soaps, perfumes and oils are included. Quality control is a term that referred to processes involved in maintaining the quality and validity of the manufactured product. In the evaluation of herbal cosmetics, we include microscopic evaluation, determination of ash, heavy metals, foreign matter and include micro-skeptical contamination etc. The marketing analysis of all herbal cosmetic products is very essential to be carried out [95-97].

Various marketed herbal cosmetic products are available for skin, hairs, lips, eyes etc. herbal cosmetics are more beneficial in the cosmetic and therapeutic application than other synthetic cosmetics. The herbal cosmetics are defined as which are having various herbal ingredients and herbal extracts. The best thing about the herbal cosmetics is that it is purely made by the herbs and shrubs $[98,99]$.

Herbal cosmetics are also known as "natural" and "Ayurvedic" cosmetics. Natural beauty care products are in presence from when the men began to utilize the cosmetic items. In this way, they are the most seasoned items utilized by humanity. Some common beautifying agents incorporate creams, face packs and scrubs, hair oils, hair hues, shampoos, hair conditioners, lipsticks, blush on or rouge as it is at times known, eyeliners, mascaras, foundations and eyeshadow, perfumes and scent, cleansers, and so forth. The detailing of all these restorative items incorporates an expansion of different regular added substances like oils, waxes, normal hues, common aromas and parts of plants like leaves, blooms and so forth by particular definition techniques [100-102].

Quality control for the efficacy and safety of herbal cosmetic products is of paramount importance. So, quality control test must be carried out for herbal cosmetics. Microscopic evaluation is indispensable in the initial identification of herbs [103-105]. And other evaluations methods for identifying the presence of ash, foreign matters, contaminants, heavy metals should be carried out for safe and good quality cosmetic products. There are a few noteworthy strides in herbal products production beginning with herbal yield planting to production and promoting. Increasingly, consumers are looking for products which have less impact on the environment. Today, the cosmetics are more "eco-friendly". Certain processes on the raw materials used in the formulation of the test and the use of the test to evaluate the effectiveness and toxicology creating a larger impact on the cosmetic product and this causes the search for this type of product by the consumers [106-108]. For products to be categorized by natural or organic these guidelines and standards established by the regulatory agencies should be followed, but there isn't a harmonization between them. These standards are designed to establish the allowed packaging processes and propose a sustainable extraction and allowed processes [109112]. Various challenges in formulating herbal cosmetics have been overcome through various novel delivery systems [113-114].

\section{CONCLUSION}

Formulating natural or organic cosmetics is the challenge to guarantee stability, safety, and efficiency. On the other hand, there is no harmonization of the guidelines related to regulatory perspectives. Many natural products can be used in cosmetic products which perform a biological function. The use of plants and herbs tends to increase in the market of cosmetic products with more sustainable market share. Therefore, there is a need for harmonized standards for herbal cosmetic products and the standardization of raw materials.

\section{AUTHORS CONTRIBUTIONS}

All the author have contributed equally

\section{CONFLICTS OF INTERESTS}

The authors do not have any conflicts of interest

\section{REFERENCES}

1. Joshi H. Potentials of traditional medicinal chemistry in the cosmetology industry; prospective and perspectives. Anaplastology 2012;1:3.

2. Sahu AN, Jha S, Dubey SD. Formulation and evaluation of curcuminoid based herbal face cream. Indo Global J Pharm Sci 2011;1:77-84.

3. Pandey S, Meshya N, Viral D. Herbs play an important role in the field of cosmetics. Int J Pharm Tech Res 2010;2:632-9. 
4. Gediya SK, Mistry RB, Patel UK, Blessy M, Jain HN. Herbal plants: used as cosmetics. J Nat Prod Plant Resour 2011;1:24-32.

5. Saha R. Cosmeceuticals and herbal drugs: practical uses. Int J Pharm Res Allied Sci 2012;3:59-65.

6. Sharma HD, Paramesh R. Trends in ageing and skin care: Ayurvedic concepts. J Ayurveda Integr Med 2010;1:110-3.

7. Top 7 Advantages of using Natural Cosmetics. Available from: www.thenewecologist.com. [Last accessed on 12 Nov 2018]

8. Akinyele BO, Odiyi AC. Comparative study of the vegetative morphology and the existing taxonomic status of Aloevera. J Plant Sci 2007;2:558-63.

9. Escamilla M, Ferre A, Hidalgo C, Fuentes N, Kaps R. Revision of European ecolabel criteria for soaps, shampoos and hair conditioners. Joint Res Centre Eur Commission Int J Pharm Sci 2012:8:1-40.

10. Suzuki D. The "Dirty Dozen" Ingredients Investigated in the David Suzuki Foundation Survey of Chemicals in Cosmetics; 2010;1-15. Available from: https://davidsuzuki.org/wpcontent/uploads/2017/10/dirty-dozen-cosmetics-ingredientsbackgrounder.pdf. [Last accessed on 01 Dec 2017]

11. Database. On occupational exposure to hazardous agents. Available from: https://coldwarpatriots.org/database-ofoccupational-exposure-to-hazardous-agents-hazmap/. [Last accessed on 02 Dec 2017].

12. International Agency for Research on Cancer (IARC) Monographs on the Evaluation of Carcinogenic Risks to Humans 1978;84:1365.

13. Kadam VS, Chintale AG, Deshmukh KP, Nalwad DN. Cosmeceuticals an emerging concept: a comprehensive review. Int J Res Pharm Chem 2013;3:308-16.

14. Winter RA. Consumers dictionary of cosmetic ingredients. Three Rivers press United states USA. 7th ed.; 2009. Available from: https://www.amazon.com/Consumers-Dictionary-Food-

Additives-7th/dp/0307408922. [Last accessed on 21 Nov 2017]

15. Upadhyaya SC. Ratirahasya (13 $3^{\text {th }}$ Cen A. D.) Mumbai: D. R. Taraporevala Sons and Co. Pri. Ltd; 1965. p. 96.

16. Bhishagaratna KL. An english translation of sushruta-samhita (176-340 A. D)-the chokhamba sanskrit series office, Varanasi: Chapter 20:37.5.; 1963. p. 455.

17. Bhishagaratna KL. Atridev-vagbhat--ashtang hridaya-shri vagbhatvirachita (Later half of $5^{\text {th }}$ Cen $A . \quad$ D.) Varanasi: Chaukhamba Sanskrit Series Office; 1962.

18. Sharma T. Nagarasarvaswam-padmashrivirachit (10thCen. A. D.) manilal desai, Fort, MumLad GP. Archeology and Mahabharata. Pune: Deccan College Postgraduate Research Institute; 1978.

19. Patkar KB, Bole PV. Herbal cosmetics in ancient India with a treatise on planta cosmetic. Bharatiya Vidya Bhavan Mumbai, India Mumbai: World Wide Fund for Nature; 1997.

20. Rao SA. Sri Sarabhendra Vaidya Ratnavali. In: Krishnaswami Mahadick. editor. Saraswati Mahal Library: Tanjore; 1952. p. $277,351,4,9,81$.

21. Mukerji B. The Indian pharmaceutical codex-council of scientific and industrial research. Council of Scientific and Indrustrial Research. Vol. 1. New Delhi; 1953. p. 223-8.

22. Rao SA. Sri sarabhendra vaidya ratnavali. In: Krishnaswami Mahadick. editor. Saraswati Mahal Library: Tanjore; 1952. p. $277,351,354,359,381$

23. Watson JF. Index to the native and scientific, names of economic plants. In: Eyre GE, Spottiswoods W. editors. London; 1866. p. 412.

24. Anon. Maharashtra State Gazetteer. Vol. A. Mumbai: Bot Gen Miscellaneous Plants-Govt Printing Press; 1961. p. 84. Part III.

25. Mishra J. Shri Kamaratnam-Nityanathvirachitam (13th Cent. A. D.) Kalyan, Lakshmi Venkatesswar Prakashan: Mumbai; 1897. p. 93.

26. Lal BB. The Saraswati flows on: The Continuity of Indian Culture; 2002

27. Mahabharata. Bhandarkar oriental research institute. Viratparva. Chap.3:17, 8:16, Aadiparva. Chap. 213:44.

28. Lad GP. Archeology and Mahabharata. Pune: Deccan college postgraduate research institute; 1978.

29. Notes of Guidance for Testing of Cosmetic Ingredients for Their Safety Evaluation. $4^{\text {th }}$ rev; 2000. Available from: https://ec.europa.eu/health/scientific_committees/consumer_ safety/docs/sccs_s_006.pdf. [Last accessed on 04 Dec 2017].
30. Oakland JS. Management tools in the manufacture of chemicals: statistical quality control. Chem Ind 1981;16:562-7.

31. Pierre M. Sampling of particulate materials theory and practice. $2^{\text {nd }}$ ed. New York; 1979.

32. Sommer K. Sampling of powders and bulk materials. Heidelberg Springer-Verlag; 1986. Available from: https://books.google.co.in/ books?hl=enandlr=andid=SDD6CAAAQBAJandoi=fndandpg=PA1a nddq $=32 .+$ Sommer+K.+Sampling + of + powders + and + bulk + materia ls.+Heidelberg,+Springer-

Verlag,+1986andots=z964KFqSY_andsig=816KsydN1-

RC2KFNOVzx5X-yeJw\#v=onepageandqandf=false. [Last accessed on 07 Jan 2017]

33. Sampling procedures for inspection by attributes. Procedures for assessment of stated quality levels. British Standard BS 60015:2000. Geneva, International Organization for Standardization; 1999. Available from: http://www.who.int/ medicines/areas/ quality_safety/quality_assurance/GuidelinesSamplingPharmPro ductsTRS929Annex4.pdf [Last accessed on 21 Jan 2018]

34. Sampling procedures for inspection by variables. Specification for single sampling plans indexed by acceptable quality level (AQL) for lot-by-lot inspection. British Standard BS 6002-1. Geneva, International Organization for Standardization; 1989. Available from: https://www.iso.org/standard/9602.htm. [Last accessed on 21 Nov 2018]

35. Sampling procedures for inspection by attributes. Sampling schemes indexed by acceptance quality limit for lot-by-lot inspection. British Standard BS 6001-1. Geneva, International Organization for Standardization; 1999. p. 2859-1. Available from: https://www.iso.org/obp/ui/\#iso: std: iso: 2859:-1:ed2:en. [Last accessed on 20 Dec 2017]

36. American National Standards Institute/American Society for Quality. Sampling procedures and tables for inspection by attributes. Washington, DC, American Society for Quality; 1993 Available from: http://vcg1.com/files/ANSI_ASQC-Z1.4. pdf. [Last accessed on 02 Nov 2017]

37. Methods for sampling chemical products. Introduction and general principles. British Standard BS 5309-1. London, British Standards Publishing; 1976. Available from: www.who.int/medicines/areas/quality_safety/./QualityAssura ncePharmVol2.pdf. [Last accessed on 26 Jan 2018]

38. Methods for sampling chemical products. Sampling of liquids. British Standard BS 5309-3. London, British Standards Publishing; 1976. Available from: www.who.int/medicines/ areas/quality_safety/./QualityAssurancePharmVol2.pdf. [Last accessed on 22 Jan 2018]

39. US Food and Drug Administration. Guidance for Industry: Botanical drug products; 2004. Available from https://www.fda.gov/downloads/Drugs/GuidanceCompliance RegulatoryInformation/Guidances/ucm070491.pdf. [Last accessed on 23 Jan 2018]

40. Geneva, Switzerland: World Health Organization Operational Guidance: Information Needed to Support Clinical Trials of Herbal Products. (Document reference (who/TDR/GEN/Guidance/051); 2005. Available from: www.who.int/tdr/publications/tdrresearch-publications/operational-guidance/en/. [Last accessed on 21 Dec 2017]

41. Acceptance sampling plans and procedures for the inspection of bulk materials. Geneva, International Organization for Standardization; 2000. Available from: https://www.iso.org/ standard/33418.html. [Last accessed on 14 Nov 2017]

42. Ernst E, Siev-Ner I, Games D. Complementary medicine-a critical review. Isr J Med Sci 1997;33:808-15.

43. Kleinman A, Eisenberg L, Good B. Culture, illness, and care: clinical lessons from anthropologic and cross-cultural research. Ann Intern Med 1978;88:251-8.

44. Bundesverb and Deutscher Industrie und Handelsunternehmen (BDIH) in Germany; Available from https://www.bdih.de/. [Last accessed on 12 Jan 2018]

45. Soil Association Organic Standard in United Kingdom. Available from: https://www.soilassociation.org/certification/. [Last accessed on 14 Jan 2018]

46. Cosmetics Organic Standard (Cosmos) in European Union (EU). Available from: https://cosmos-standard.org/. [Last accessed on 02 Dec 2017].

47. ECOCERT in France. Available from: www.ecocert.in. [Last accessed on 10 Nov 2017] 
48. National Association for Sustainable Agriculture, Australia (NASAA) in Australia. Available from: https://www. nasaa.com.au. [Last accessed on 16 Dec 2017]

49. Istituto per la Certificazione Etica e Ambientale (ICEA) in Italy. Available from: http://icea.bio/. [Last accessed on 27 Dec 2017]

50. InstitutoBiodinâmico de Certificações (IBD) in Brazil. Available from: http://ibd.com.br/pt/IbdOrganico.aspx. [Last accessed on 13 Nov 2017]

51. Oregon Tilth in the United States of America; Available from https://tilth.org/. [Last accessed on 10 Nov 2017]

52. Kambooj A. Anaytical Evaluation of Herbal Drugs. Available from: http://cdn.intechopen.com/pdfs/32437/InTech-Analytical_ evaluation_of_herbal_drugs.pdf. [Last accessed on 21 Jan 2018]

53. Skoog DA, West DM, Holler FJ. Fundamentals of analytical chemistry. $8^{\text {th }}$ ed. Fort Worth: Saunders College Pub; 1996. Available from: https://www.pdfdrive.com/title-fundamentals -of-analytical-chemistry-8th-edition-student-e4247391.html. [Last accessed on 06 Dec 2017].

54. Swartz ME, Krull IS. Analytical method development and validation. Marcel Dekker, Inc; New York: 1997. Available from: https://pubs.acs.org/doi/abs/10.1021/ja975573z. [Last accessed on 10 Nov 2017]

55. Food and Drug Administration. Current Good Manufacturing Practice for Finished Pharmaceuticals. Available from: http://www.accessdata.fda.gov/scripts/cdrh/cfdocs/cfcfr/CFR Search.cfm?CFRPart=211. [Last accessed on 08 Dec 2017]

56. Food and Drug Administration. Current Good Manufacturing Practice in Manufacturing, Packaging, Labelling, or Holding Operations for Dietary Supplements. Available from: http://www.accessdata.fda.gov/scripts/cdrh/cfdocs/cfcfr/CFR Search.cfm?CFRPart=111. [Last accessed on 08 Dec 2017]

57. International Conference on Harmonisation of Technical Requirements for Registration of Pharmaceuticals for Human Use, Validation of Analytical Methods: Definitions and Terminology; Geneva, Switzerland: ICH Secretariat; 2010. Available from: http://www.ich.org/cache/compo/276-2541.html. [Last accessed on 14 Dec 2017]

58. Center for Drug Evaluation and Research, Center for Biologicals Evaluation and Research, Food and Drug Administration. Guidance for Industry-Analytical Procedures and Methods Validation-Chemistry, Manufacturing, and Controls Documentation Draft Guidance. Department of Health and Human Services; Rockville, MD; 2000. Available from: http://www.msk.nclinnovations.org/medregulations/v1/html /Guidance/Guidance_Analytical\%20Method\%20and\%20Valida tion.pdf [Last accessed on 02 Jan 2018]

59. AOAC International. Single Laboratory Validation Acceptance Criteria (Chemical Methods) AOAC International; Gaithersburg, MD; 2002. Available from: http://www.aoac.org/ dietsupp6/ Dietary-Supplement-web-site/SLV_criteria.pdf. [Last accessed on 04 Dec 2017]

60. AOAC International. Single Laboratory Validation-Generic Protocol. AOAC International; Gaithersburg, MD; 2002. Available from: http://www.aoac.org/dietsupp6/Dietary-Supplement-website/SLVGeneric.pdf. [Last accessed on 07 Nov 2017]

61. AOAC International. Method Validation. AOAC International; Gaithersbrg, MD; 2010. Available from: http://www.aoac.org/ vmeth/omamanual/omamanual.htm. [Last accessed on 02 Jan 2018]

62. Chadwick L, Fong H. Herb quality assurance and standardization in herb-drug interaction evaluation and documentation. Lam YW, Huang SM, Hall SD, editors. New York: Taylor and Francis. Herb quality assurance and standardization in herb-drug interaction evaluation and documentation; 2006. p. 191-203.

63. Geneva: World Health Organization; World Health Organization. Regulatory Situation of Herbal Medicines. A Worldwide Review; 1998. Available from: http://apps.who.int/iris/handle/ $10665 / 63801$ [Last accessed on 03 Nov 2017]

64. Fong HH. Integration of herbal medicine into modern medical practices: issues and prospects. Integr Cancer Ther 2002;1:287-93.

65. Geneva: World Health Organization. WHO Guidelines on Good Agricultural and Collection Practices (GACP) for Medicinal Plants. 2003 Available from http://apps.who.int/iris/ bitstream/handle/10665/42783/9241546271.pdf.jsessionid=
09F846F1069DF6BEC23747D3C280EF8E?sequence=1. [Last accessed on 15 Jan 2017]

66. Geneva: World Health Organization. General Guidelines for Methodologies on Research and Evaluation of Traditional Medicine. WHO/EDM/TRM; 2000. Available from: http:// apps.who.int/iris/handle/10665/66783. [Last accessed on 20 Dec 2017]

67. Geneva: World Health Organization. Legal Status of Traditional Medicine and Complementary/Alternative Medicine: A Worldwide Review. WHO/EDM/TRM; 2001. Available from: http://apps.who.int/medicinedocs/en/d/Jh2943e/. [Last accessed on 21 Nov 2017]

68. Nadkarni KM. Indian plants and drugs with their medicinal properties and uses. Norton and Co. Madras; 1910. p. 120.

69. World Health Organization. Guidelines for the regulation of herbal medicines in the South-East Asia Region. New Delhi, Regional Office for South-East Asia; 2003. Available from: http://apps.who.int/medicinedocs/en/m/abstract/Js22299en /. [Last accessed on 05 Nov 2017].

70. Skalli S, Soulaymani Bencheikh R. Safety monitoring of herbdrug interactions: a component of pharmacovigilance. Drug Saf 2012;35:785-91.

71. Shetti S, Kumar CD, Sriwastava NK, Sharma IP. The growing use of herbal medicines: Issues relating to adverse reactions and challenges in monitoring safety. Front Pharmacol 2014;4:1-10.

72. Cairo: World Health Organization (WHO), Regional Office for the Eastern Mediterranean; World Health Organization. Guidelines on minimum requirements for the registration of herbal medicinal products in the Eastern Mediterranean Region; 2006. Available from: https://www.paho.org/ blz/index.php?option=com_docmanandview=downloadandalia $s=223$-2006-working-together-for-healthandcategory_slug= technical-documentationanditemid $=250$. [Last accessed on 08 Nov 2017]

73. Development of Traditional Medicine in the South-East Asia Region. Report of a Regional Consultative Meeting Pyongyang, DPR Korea. World Health Organization, Regional Office for South-East Asia New Delhi; 2005. Available from: http://apps.searo.who.int/PDS_DOCS/B0020.pdf. [Last accessed on 10 Jan 2018]

74. Bensoussan A, Talley NJ, Hing M, Menzies R, Guo A, Ngu M, et al. Treatment of irritable bowel syndrome with Chinese herbal medicine: a randomized controlled trial. JAMA 1998;280:1585-9.

75. Barens J, Anderson, Phillipson JD, Newall CA. Herbal Medicines. Vol. 459: London. Pharmaceutical Press; 2007. p. 1-23.

76. Quality criteria and standardization of phytopharmaceuticals: Can acceptable drug standards be achieved? Drug Inform J 1994;32:101-10.

77. Bodeker C, Bodeker G, Ong CK, Grundy CK, Burford G, Shein K. WHO global atlas of traditional, complementary and alternative medicine. World Health Organization, Geneva. De Smet PAGM; 2004. Available from: http://apps.who.int/iris/bitstream/ handle/10665/43108/9241562862_map.pdf?sequence=1. [Last accessed on 23 Dec 2017]

78. Keller K, Hansel R, Chandler RF, Smet D. Health risks of herbal remedies. Drug Saf 1992;13:81-93.

79. Duke JA, Martinez RV. Overview of herbal quality control. Drug Inform J 1994;33:717-24.

80. European Agency for the Evaluation of Medicinal Products (EMEA), London. EMEA. Points to Consider on Good Agricultural and Collection Practice for Starting Materials of Herbal Origin; 2002. Available from: http://www.ema. europa.eu/docs/en_GB/document_library/Other/2009/12/W C500018057.pdf. [Last accessed on 07 Oct 2017]

81. Kunle, Folashade O, Egharevba, Omoregie H, Ahmadu, Ochogu P. standardization of herbal medicines-a review. Int J Biodiver Conserve 2012;4:101-12.

82. WHO. Basic Tests for Drugs, Pharmaceutical Substances, Medicinal Plant Materials, and Dosage Forms. World Health Organization, Geneva; 1998. Available from: https://books. google.co.in/books?isbn=9241545372. [Last accessed on 26 Jan 2018]

83. WHO, General Guidelines for Methodologies on Research and Evaluation Traditional Medicine. World Health Organization, 
Geneva; 2002. Available from: http://apps.who.int/ medicinedocs/ en/d/Jwhozip42e/. [Last accessed on 02 Jan 2018]

84. EMEA guidelines on Quality of Herbal Medicinal Products/ Traditional Medicinal Products, Review. European Agency for the Evaluation of Medicinal Products (EMEA), London; 2005. Available from: http://www.ema.europa.eu/ docs/en_GB/document library/Scientific_guideline/2011/09/WC500113209.pdf. [Last accessed on 21 Nov 2017]

85. WHO, Quality Control Methods for Medicinal Plant Materials. World Health Organization, Geneva; 1992. Available from: http://apps.who.int/iris/handle/10665/41986. [Last accessed on 20 Dec 2017]

86. Adenan MI. Malaysian herbs and herbal products. In A Two and Half Day Course of Herbal and Phytochemical Processing, CEPP short course notes. Chemical Engineering Pilot Plant, UTM, Skudai; 2003. Available from: http://eprints.utm.my/id/eprint/ 54831/ 1/NorAmaizaMohdAminPFChE2015.pdf. [Last accessed on $22 \mathrm{Nov}$ 2017]

87. Arif MT. Traditional/Complementary Medicine: The way ahead. Med J Malasyia 2002;57:261-4.

88. Puteh M. In a Two and Half Day course of Herbal and Phytochemical Processing, CEPP short course notes. Chemical Engineering Pilot Plant, UTM Skudaijanuary; 2003. Available from: http://www.kolmetz.com/pdf/Foo/IJKM_Phytochemical.pdf. [Last accessed on 17 Jan 2017]

89. Wazir SK. promoting the herbal industry in Malaysia: The Malaysia Herbal Corporation Initiative. In A Two and Half Day course of Herbal and Phytochemical Processing, CEPP short course notes. Chemical Engineering Pilot Plant; 2003. Available from: http://www.ibd.utm.my/files/PDF/tc_HERBALPHYTO04(L)new.pdf. [Last accessed on 12 Jan 2018]

90. Verma S, Singh SP. Current and future status of herbal medicines. Veterinary World 2008;1:347-50.

91. Padmawar A, Bhadoria U. Phytochemical investigation and comparative evaluation of in vitro free radical scavenging activity of Triphala and Curcumin. AJMPS 2011;1:9-12.

92. Ampofo J, Andoh A, Tetteh W, Bello M. Microbiological profile of some ghanaian herbal preparations-safety issues and implications for the health professions. Open J Med Microbiol 2012;2:121-30.

93. Mosihuzzaman M, Choudhary MI. Protocols on safety, efficacy, standardization, and documentation of herbal medicine. Pure Appl Chem 2008;80:2195-230.

94. Mukama E. The African herbal industry: constraints and challenges. Available from: http://www.academia.edu/3443773/ The African_herbal_industry_constraints_and_challenges. [Last accessed on 08 Jan 2018]

95. Kamboj A. Analytical evaluation of herbal drugs. Drug Discovery; 2012. Available from: https://www.intechopen.com/books/drugdiscovery-research-in-pharmacognosy/analytical-evaluation-ofherbal-drugs. [Last accessed on 03 Jan 2017]
96. Patkar K. Herbal cosmetics in ancient India. Indian J Plast Surg 2000;41:134-7.

97. Galor SW, Benzie IFF. Editors. Herbal medicine: biomolecular and clinical aspects. an introduction to its history, usage, regulation, current trends, and research needs. $2^{\text {nd }}$ ed. Boca Raton: CRC Press; 2011.

98. Erah P. Herbal medicines: challenges, a tropical journal of pharmaceutical research armstrong $\mathrm{NC}$. Br J Clin Pharmacol 2002;1:53-4

99. Bauer R, Tittel G. Quality assessment of herbal preparations as a precondition of pharmacological and clinical studies. Phytomedicine 1996;2:193-8.

100. Bhattaram VA, Graefe U, Kohlert C, Veit M, Derendorf $H$. Pharmacokinetics and bioavailability of herbal medicinal products. Phytomedicine 2002;9 Suppl 3:1-33.

101. Brevoort P. The U. S. botanical market: an overview. Herbal Gram 2002;251:1005-19.

102. Calixto JB. Efficacy, safety, quality control, marketing and regulatory guidelines for herbal medicines (phytotherapeutic agents). Braz J Med Biol Res 2000;33:179-89.

103. Chaudhary Roy, Chandrashekharan M, Mishra S. Embryotoxicity and teratogenicity studies of ayurvedic contraceptives. J Ethnopharmacol 2001;56:300-1.

104. Chan K. Some aspects of toxic contaminants in herbal medicines. Chemosphere 2003;52:1361-71.

105. Dahanukar SA, Thatte UM. Current status of Ayurveda in phytomedicine. Phytomedicine 1997;4:359-68.

106. Eisenburg MD, David M. Coincidence in pharmaceutical discovery. The impact of biotechnology. Arzneimittel Forschung 1995;45:934-9.

107. Appel S, Wilkey S, Van Rompay M, Kessler RC. Trends in alternative medicine use in the United States, Results of a follow-up national survey. J Am Med Assoc 1998;280:1569-75.

108. Eisenberg DM, Kessler RC, Foster C, Norlock FE, Calkins DR, Delbanco TL. Unconventional medicine in the United States. New Engl J Med 1993;328:246-52.

109. Ernst E, Rand JI, Stevinson C. Complementary therapies for a depression-an overview. Arch Gen Psychiat 1998;55:1026-32.

110. Fisher P, Ward A. Complementary medicine in Europe. Br Med J Fugh-Berman 2000;309:107-11.

111. Grunwald J, Buettel, K. The European phytomedicines market: figures, trends, analysis. Herbal Gram 1995;34:60-5.

112. Marcus D, Grollman A. Botanical medicines-the need for new regulations. New Engl J Med 2002:347.

113. Sivapriya V, Ponnarmadha S, Abdul Azeezand N, Sudarshanadeepa $V$. Novel nanocarriers for ethnopharmacological formulations. Int J Appl Pharm 2018;1:26-30.

114. Alaayedi M, Mahmood H, Saeed A. The enhancement effect of castor oil on the permeability of flurbiprofen as a transdermal gel. Int J Appl Pharm 2018;10:140-4. 